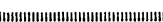

\author{
中井 康秀*・吉井 賢太*2
}

\title{
Optical Width Gauge for Hot Radiant Plates
}

\author{
Yasuhide Nakai, Kenta Yoshit, Takamasa Nakada and Itsuo Takahashi
}

\begin{abstract}
Synopsis :
An optical width gauge for hot plates has been developed, which can be installed near the rolling mill without backlight equipment. The device consists of solid state linear image sensors, a signal processor and a microcomputer. Edge points of plates are detected by finding the steepest points in the video signals of the radiant images. Furthermore, highly resolved edge data can be derived from the discrete differential signals by calculating the quadratically interpolated peak points of the signals. The edge data are stable and accurate even if the temperatures of the objects are varied.

This paper describes the method of detection for plate edges and experimental data concerned with the high resolving power. An application of the equipment is given for the camber display system which has been installed near the finishing mill in the plate shop and which displays the camber shape of plates immediately after finish rolling and gives useful information to mill operaters.
\end{abstract}

\section{1. 緒 \\ 言}

鋼板圧延工程に括いて, 幅精度の向上，拈よび幅異形， キャンバの減少は現在残されている歩留り向上対策の中 で大きな課題の 1 つである。とのため，あらかじめ最終 幅形状を予測し制御する圧延法などが実施されてきてい るが，压延中あるいは压延前後において幅や平面形状を 精度よく計測できれば, オンラインで高精度の幅, キャ ンバ制御が可能となり，より大きな効果が期待できる.

しかし, 従来圧延工程で用いられているバックライト 方式の幅計は, 設置場所, 保全性の点で, 王延機值近用 としては適さず，悪環境下で使える高精度の幅・形状計 の開発が望まれていた1)。そこで，従来精度があまり良 くなかつた放射光方式2)を見なおし，イメージセンサを 用いた高分解能幅計を開発した。当社, 厚板工場に沶い て，厚板キャンバ表示装置として適用した結果，良好な 性能を確認したので，測定原理および装置の概要，尖験 結果について報告する.

\section{2. エッジの検出方法}

\section{1 原 理}

物体より放射されるェネルギーは, 絶対温度の 4 乗に 比例するが，イメージセンサを用いて撮像した場合，分 光感度が約 $0.5 \sim 1.1 \mu \mathrm{m}$ に限られることから, その出 力は温度のさらに高次に比例する ${ }^{3)}$. Photo. 1(a) は,
仕たげ压延㨁後の厚权を撮像した時の映像信号で，エッ ジ付近のわずかな温度低トであつても，大きく映像レべ ルがトがつている．Fig. 1 は, 種々の温度の将板を撮 像した時，その映像レベルがー一定になるような走査周期 と温度の関係をふしたものである. それぞれ，対数の目 盛にすると，ほぼ直線になり，この付近の温度の板に対 するイメージセンサの出力が絶対温度の約 13 乗に比例 していることがわかる.Fig. 2 は，この結果から，各温

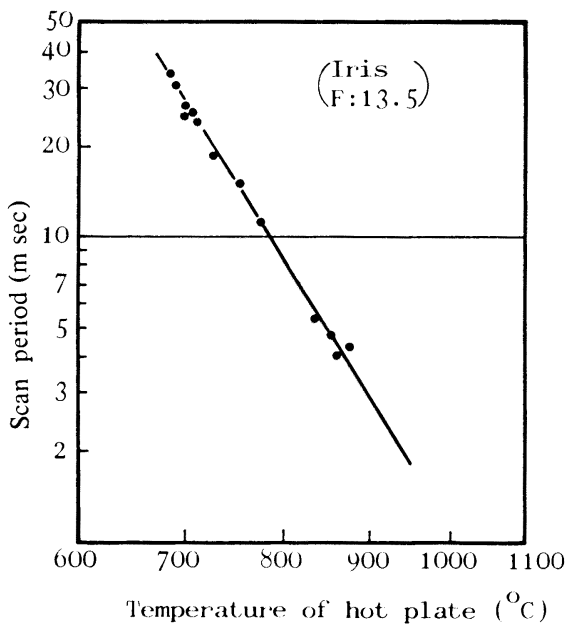

Fig. 1. Scan period of solid image sensor vs. temperature of objects when the video signal levels are constant.

昭和 58 年 11 月 14 日受付 (Received Nov. 14, 1983)

*（株）神戸製鋼所電子技術センター (Electronics Technology Center, Kobe Steel, Ltd., 53-3 Aza-Maruyama Gomo Nada-ku Kobe 657)

*2 (株) 神戸製鋼所加古川製鉄所 (Kakogawa Works, Kobe Steel, Ltd.) 


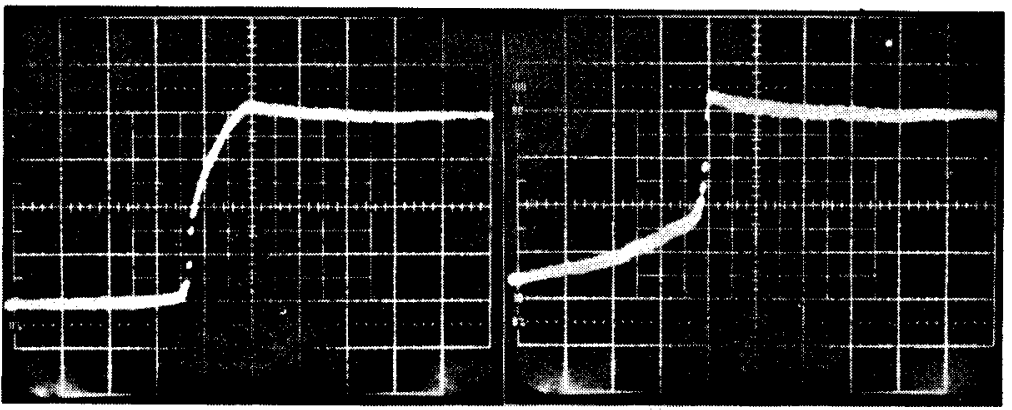

(a) normal exposure

(b) overexposure

Photo. 1. Video signals of hot plates.

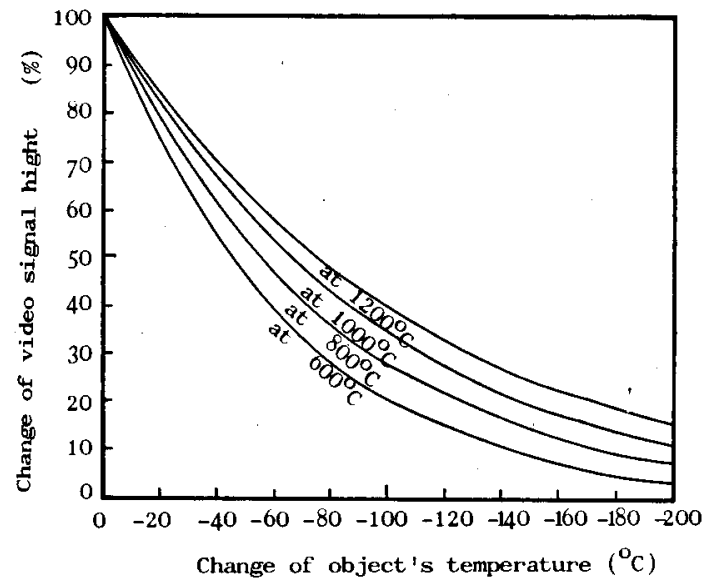

Fig. 2. Change of video signal hight vs. change of object's temperature at each temperature.

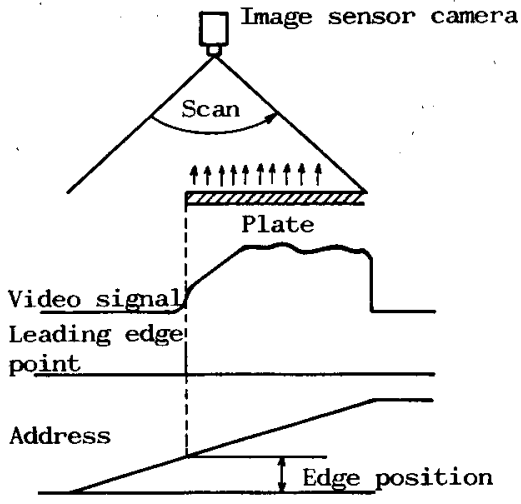

Fig. 3. Method of hot plate edge detection.

度の板を撮像した時の, 温度变化に対する出力変化を計 算したるのである。例えば， $800^{\circ} \mathrm{C}$ の板で，エッジ部の 温度が約 $120^{\circ} \mathrm{C}$ 低下すると, エッジ部の映像レベルが， $800^{\circ} \mathrm{C}$ の所の約 1/5 になることを示している，また， 露光量を多くすると,イメージセンサの場合 Photo. 1 (b) K示すようK，エッジの外をで映像レベルが上がる
現象がある.したがつて，従来のスレショールド法で は，正確なェッジ位置検出が困難になる。

しかし，板のない所から約 $900^{\circ} \mathrm{C}$ 前後の板のある所 一走査した時, 明らかにエッジ部の温度変化が一番大き く、イメージセンサの感度を適当にコントロールすれ ば，映像信号の最も急峻に立ち上がる点を見つけること によつてェッジ位置を検出できることが尒測される。

Fig. 3 は,この原理を示したるので，イメージセンサの 映像信号の差分をとり，そのピークのアドレスからエッ シ位直を検出できる。

さらに，離散的なアドレスより細かい分解能の情報を 得るため,ビークアドレス付近の差分信号レベルから内 插によつて真のピーク位置を推定した。一般に，イメー ジンサの出力は，ステップ状の明るさ变化をあたえて も, その立ち上がりの前後で, 明部に対応する画素から 暗部に対応する画素へ信号のにじみが生し，結果として あたか子低域通過フィルタを通したようになる。また， 焦点のボタやレンズの収差などによつてる映像信号から 高周波成分が除去される。しかし最す急睃に立ら上がる 点, すなわち変曲点が明部之暗部の境界を表すと考えら れ，離散的にしか得られない映像信号であつてる，その レベルから最急峻点の位置を内挿することが可能であ る. 内插の方法としては，Fig. 4 亿示すように，差分信 号のピークとその前後の信号しベルを通る放物線を考 え，その頂点の座標を真のピーク位置とした．この場 合, 元のアドレスからのずれ $\Delta m$ は，

$$
\Delta m=\frac{L_{\mathrm{m}+1}-L_{\mathrm{m}-1}}{2\left(2 L_{\mathrm{m}}-\left(L_{\mathrm{m}+1}+L_{\mathrm{m}-1}\right)\right)}
$$

ただし， $L_{\mathrm{m}+1}=V_{\mathrm{m}+1}-V_{\mathrm{m}}$

$$
\begin{aligned}
L_{\mathrm{m}} & =V_{\mathrm{m}}-V_{\mathrm{m}-1} \\
L_{\mathrm{m}-1} & =V_{\mathrm{m}-1}-V_{\mathrm{m}-2}
\end{aligned}
$$

$m:$ 差分信号ピーク発生のアドレス

$V_{\mathrm{m}+1}, V_{\mathrm{m}}, V_{\mathrm{m}-1}, V_{\mathrm{m}-2}$ ：映像信号レベル

である. $\Delta m$ は -0.5 から 0.5 の間流り， 


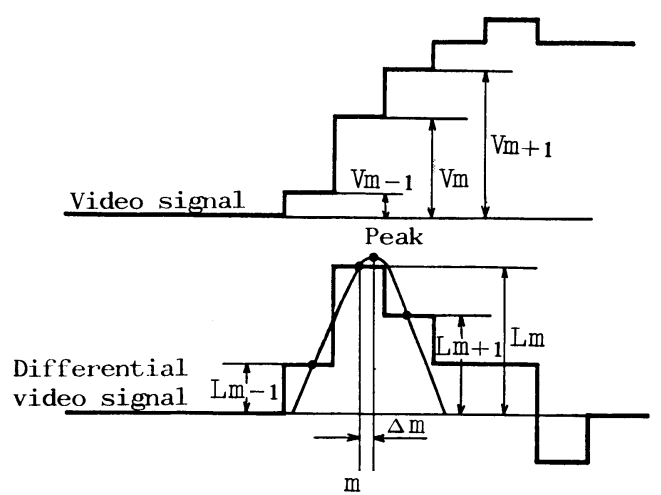

Fig. 4. Method of detecting high resolved edge position using quadratical interpolation of differential video signal peak.

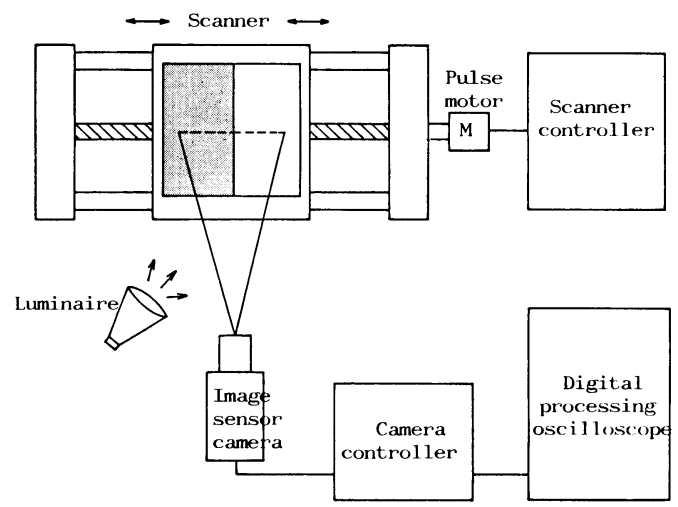

Fig. 5. Experimental apparatus for detecting high resolved edge position.

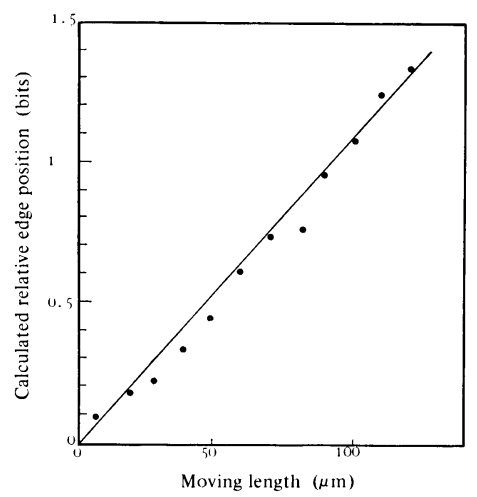

Fig. 6. Experimental results of detection of highly resoluved edge position.

$$
x=P \cdot(m+\Delta m)
$$

ただし，

$P:$ 撮像面上での 1 画素あたりの長さ $(P=d / m \quad d:$ : メージセンサ画素ピッチ

$$
m \text { : 光学倍率) }
$$

によつて, エッジ位置 $x$ が計算できる.

\section{$2 \cdot 2$ 確認実験}

(1)，（2）式によつて求まる高分解能のエッジ位置 と, 実際のエッジ位置の相対的な变化を調べるため, Fig. 5 で示す構成の装置を用いて㬰験した。模擬的な エッジをディジタルコントロール可能な久キャナで動か し，その時のイメージセンサの映像信当を，メモリ付才 シロスコープを使つて計算機にとり込み，(1)，(2)式 の計算を行つた。 Fig. 6 は，その結果である. 横軸は, スキャナで動かした模擬ェッジの位算で，縦軸は，それ ぞれの位真に打ける映像信号から（1），(2)式によつて 求めたエッジ位蒋である。ただし， $P$ は 1 とした。従 米，イメージセンサの映像信号が時間的に不連続であつ たため，1画素より小さい位㯰情報は得ることができな かつたが，図に示すよりに，計算で求めたエッジ位置 は，模擬エッジの位㯰とほほ連絖的に対忍している。困 のばらつきから推定すると，1画素の約 1/10の精度 で，エッジ位㯰を内㨂できると高える。また，絞りや照 明を变化させ，エッジ位罱の明るさに対する計算值の変 動を調べたが， 1 画素の $1 / 3$ 程度までは十分，分解でき ることがわからた。

\section{3. 厚板キャンバ表示装置}

\section{1 構 成}

本装置は,仕上げ圧延值後の厚板キャンバ形状をCRT ディスプレイに払大表示するもので，イメージセンサカ メラ 2 台, 信号処理装置, PLG (Pulse Generater), PL $\mathrm{G}$ 分周器, 表小用マイクロコンピュータ, GRT ディス プレイ,グシフィックプリンタから構成される. Fig. 7

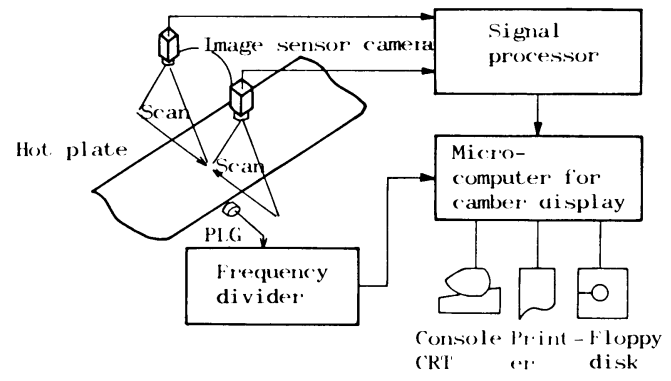

Fig. 7. Configuration of the equipment for camber display.

に，全体のブロック咸を亦す.

イメージセンサカメラは, 仕上げ生延機出側の搬送テ ーブル上に設置した. Table 1 にセンサの仕様を示す. 信号処理装监は, カメラ駆動用信等を作るカメラ制御 
Table 1. Characteristics of sensor.

\begin{tabular}{ll}
\hline Device & MOS type image sensor \\
Number of elements & 1024 \\
Lens & f $50 \mathrm{~mm}$ (Macro) \\
Range of vision & about $2000 \mathrm{~mm} /$ camera \\
Distance between two cameras & about $2700 \mathrm{~mm}$ \\
Resolusion & about $0.5 \mathrm{~mm}$ \\
Size of object & $700 \sim 4700 \mathrm{~mm}$ \\
Scan period & $3 \sim 40 \mathrm{~ms}$ \\
Sampling pitch & $300 \mathrm{~mm}$ \\
Temperature range of objects & $700 \sim 900^{\circ} \mathrm{C}$ \\
\hline
\end{tabular}

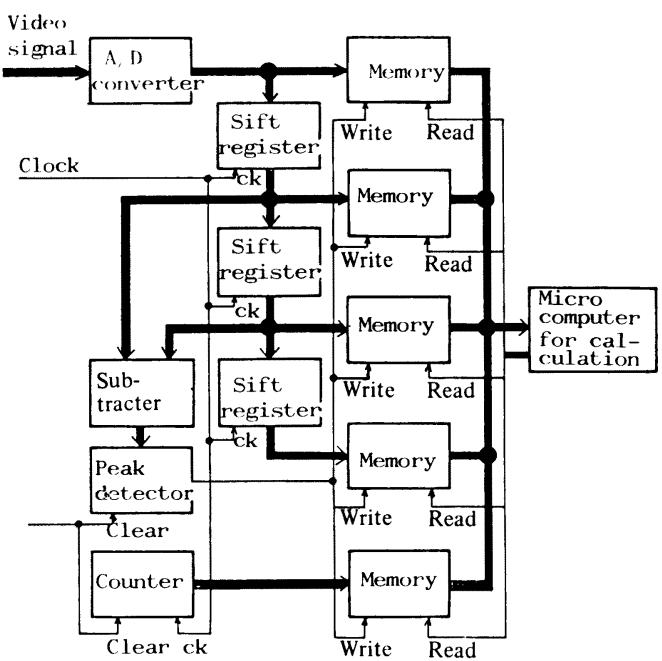

Fig. 8. Block-diagram of signal processing for differential signal peak detection.

部，エッジ検出に適当な映像信号レベルを得るように走 查周期をコントロールする AGC (Automatic Gain Control) 部, 映像信劣を $\mathrm{A} / \mathrm{D}$ 変換して差分ピークを 検出するエッジ検出部, 高分解能のエッジ位置を計算す るCPU 演算部からなる。

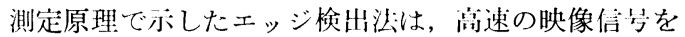
扱らため，装分ピーク优睤のアドレン $(m)$ を検出する ところまでをハードウェアで処理し, 角述の (1)，(2) 式の計算は，ソフトウェアで処理した。 そのため，Fig. 8 のような问路を構成した。

PLG 分周器は, 搬送テーブル駆動用モータに直結し た PLGのパル久を分周することによつて，厚板が一走 表さ通過与るごとに表示用マイイクロコンピュータに割り 込みをかける。

表示用ーイクロコンピュータでは, .L記割り込みに従

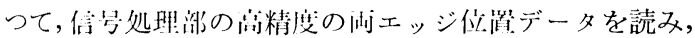
板通過後, 厚板キャンバ形状の表示と平均幅の計算など を行う。また，オペレータの要求に伈じて， CRT 画面 のハードコピーをとれるようにした.

\section{$3 \cdot 2$ キャンバ形状表示ソフトゥェア}

厚板のサイズは, 幅約 $1.0 \sim 4.6 \mathrm{~m}$, 長さ約 $5 \sim 45 \mathrm{~m}$

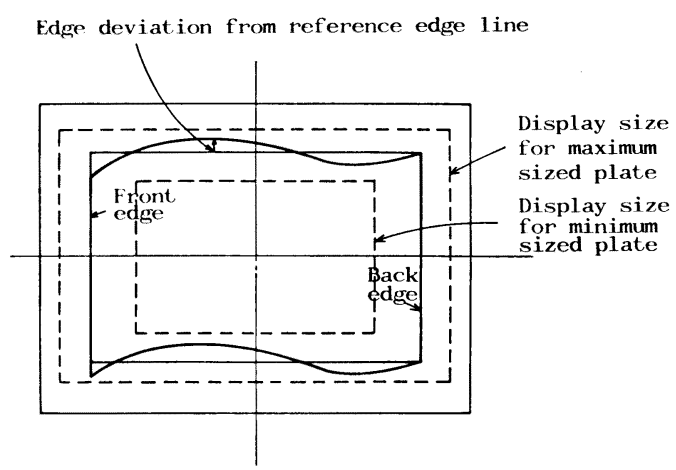

Fig. 9. Format of camber display.

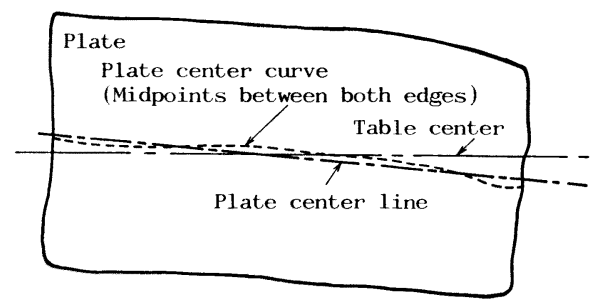

Fig. 10. Plate center line caluculated by regression of midpoints between both edges.

と公範囲にわたる。一方，キャンバ量は，10４0 mm の オーダである。 したがつて，一定の縮人で表示すると， 表示画面上でキャンバがほとんど表現されず，また小さ いサイズの板の表示も小さくなりすぎる，例えば，4.6 $\mathrm{m} \times 45 \mathrm{~m}$ の板を $200 \mathrm{~mm} \times 250 \mathrm{~mm}$ の画面いつぱいに表 示できるよらにすると $1 \mathrm{~m} \times 5 \mathrm{~m}$ の板は, $43 \mathrm{~mm} \times 28$ $\mathrm{mm}$ に表示され, $20 \mathrm{~mm}$ のキャンバは, 約 $1 \mathrm{~mm}$ にな る. そこで, Fig. 9 に示すよらに最大サイズの板の表 示寸法を画面ほぼいつぱいにとり, 最小サイズの板の表 示寸法を画面の縦, 横とれぞれ $1 / 2$ 程度になるように 定め, その間, 板幅, 長さに応じてそれぞれ表示寸法を 変えるようにした．また，板の中心線が搬送テーブルの 方向に対して傾いたまま, 板が移動する場合を考慮し て, Fig. 10 に示すように, 両エッジの中心群の回㷌直 線を板の中心線とし，中心線からのエッジ位置を求めな 扎した。エッジ位置の表現は，平均幅の長方形の板を基 準とし，それからのずれを拡大表示した。 Fig. 11 に， 表示例を示す.

\section{4. キャンバ測定精度の確認}

厚板キャンバ形状表示装置のオンライン測定精度を確 認するため, 同装置の出力と, 冷間に打梳る実測值との 対応実験をした。冷間に拈ける実測方法としては, エッ ジから約 $100 \mathrm{~mm}$ のところに, 水糸を用いて基準線を作 


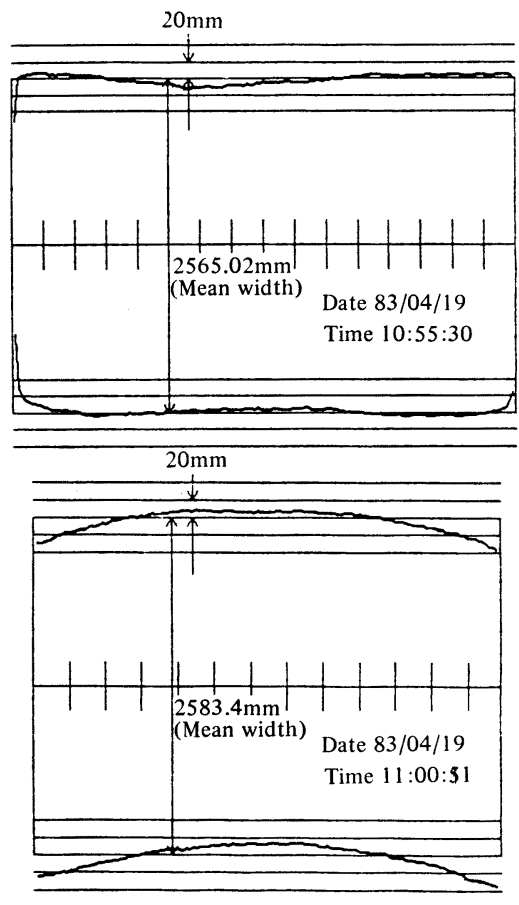

Fig. 11. Examples of camber display.

り $2 \mathrm{~m}$ ごとに基準線からエッジまでの距離を測定する ことによつて, キャンバ形状を把握した。. 次に, 冷間の データを前述のマイクロコンピュータにインプットし， フロッピディスクに記憶させたオンラインデータと命わ せてキャンバ形状表示画面を再現した。冷間のデータを 重ね書きする時，先後端からそれぞれ 2 番目の冷間尖測 点をキャンバ表示の出力に合わせ, 計算した水系シイン を基準として他の冷間実測点をプロットした。また，精 度を確認するため, それぞれの点におけるオンラインデ 一タとの差, それらの誤差平均, 偏り, 標準偏差を求め た。

Fig. 12 に結果の一例を示す。 また，Fig. 13 に愦差 分布を示す. 先後端から 2 点目の所で誤差があれば，そ の誤差が全体に加算されるので，あまり良い対応のとり 方ではないが, 標準偏差 $2.5 \mathrm{~mm}$ といら結果を得た. 冷間実測の精度，板の蛇行，上ぞりなどを考慮すれば十 分小さな值であり, キャンバ表示装監としては満足のい く性能と言える。

\section{5. 結言}

放射光式の幅計において，映像信号の差分のピーク位 置を見つけることによつて，対象物体の温度変化に対し て安定で, 高精度なェッジ位置が検出できることがわか

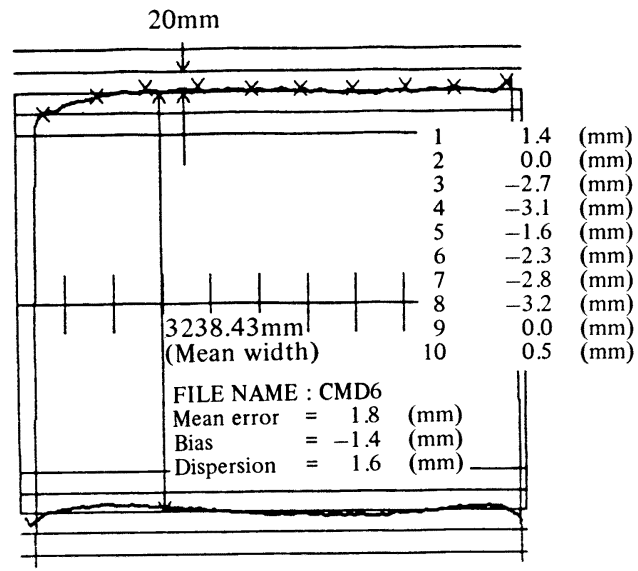

Fig. 12. Example of experimental data.

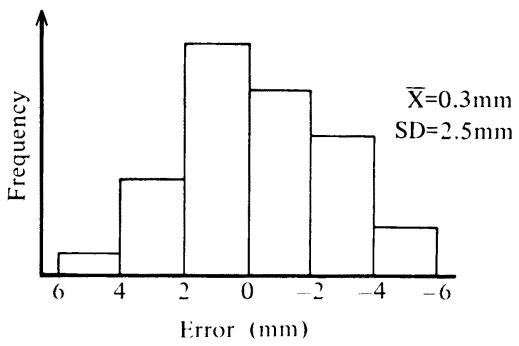

Fig. 13. Error distribution.

つた。 さらに，美分信罗のピーク付近の值を淮算するこ とにより，イメージセンサの分解能以は:の情報が得られ ることが確認できた。忍用の1つとして，厚板のキャン バ形状表示装喵を開発したが，従水日視怵難な微少キャ ンバや，人キッドによる幅埧形などが仕」:げ月延值後に 把握できるようになり，オペレータガイダンスとして有 效に利用されている。

このj式は

（1）バックシイトがないので，構造がシンブルとな る。

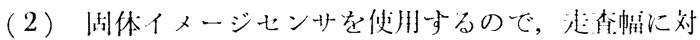
一る分解能が高い。

（3）ヒンサが小形であり，人京命も烄い。 などの特徽を持つて持り，今後，川延機自近用として， 利用されると考光られる。

\section{文献}

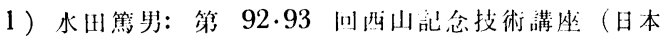
鉄鋼協会編)

2）第 3 版鉄鋼便覽 I 基礎（日本鉄鋼協会編）(1981）, p. 758 [丸善]

3 ) 豊明弘道: 放射温度测定と放射譬，第46 回温度 計測部会资料（阽测白動制御学会）(1981)，p．1 